\title{
Video Pembelajaran Fisika Sebagai Sumber Belajar Daring untuk Meningkatkan Motivasi Belajar Peserta Didik SMAN 9 Mataram di Masa Pandemi Covid-19
}

\author{
I Made Narta Widianta \\ SMA Negeri 9 Mataram, Kota Mataram - Provinsi NTB \\ Corresponding Author. Email: paknarta2020@gmail.com
}

\begin{abstract}
This study aims to increase students' learning motivation during the Covid-19pandemic through physics learning videos. The research method used is qualitative research. This research was carried out during the odd semester of the 2020/2021 academic year at SMAN 9 Mataram for 35 students of class X MIA 3 through Google Classroom and Youtube. Data collection techniques using questionnaires, interviews and observations. Based on the results of the questionnaire analysis of students' learning motivation, it was found that the application of physics learning videos as a learning resource caused students to have an average score of 54 (high category). Some of the students, namely $40 \%$ have learning motivation in the very high category, $49 \%$ in the high category, and $11 \%$ in the medium category. Thus, it can be concluded that the application of physics learning videos as a learning resource for students of class X MIA 3 SMAN 9 Mataram during the Covid-19pandemic can generate motivation to learn physics with the average student having motivation to learn in the high category.
\end{abstract}

\begin{abstract}
Abstrak: Penelitian ini bertujuan untuk meningkatkan motivasi belajar peserta didik di masa pandemi Covid-19 melalui video pembelajaran fisika. Metode penelitian yang digunakan adalah penelitian kualitatif. Penelitian ini dilaksanakan selama semester ganjil tahun pelajaran 2020/2021 di SMAN 9 Mataram pada peserta didik kelas X MIA 3 yang berjumlah 35 orang melalui Google Classroom dan Youtube. Teknik pengumpulan datanya menggunakan angket, wawancara dan observasi. Berdasarkan hasil analisis angket motivasi belajar peserta didik diperoleh bahwa penerapan video pembelajaran fisika sebagai sumber belajar menyebabkan peserta didik memiliki nilai rata-rata pada skor motivasi belajar sebesar 54 (kategori tinggi). Sebagian peserta didik yaitu sebesar 40\% memiliki motivasi belajar dalam kategori sangat tinggi, 49\% dalam kategori tinggi, dan $11 \%$ dalam kategori sedang. Dengan demikian dapat disimpulkan bahwa penerapan video pembelajaran fisika sebagai sumber belajar bagi peserta didik kelas X MIA 3 SMAN 9 Mataram selama masa pandemi Covid-19dapat membangkitkan motivasi belajar fisika dengan rata-rata peserta didik memiliki motivasi belajar pada kategori tinggi.
\end{abstract}

\author{
Article History \\ Received: 22-05-2021 \\ Revised: $15-06-2021$ \\ Accepted: 23-06-2021 \\ Published: 07-07-2021
}

\author{
Key Words: \\ Physics Learning Video, \\ Online, Learning \\ Motivation.
}

\section{Sejarah Artikel}

Diterima: 22-05-2021

Direvisi: 15-06-2021

Disetujui: 23-06-2021

Diterbitkan: 07-07-2021

\section{Kata Kunci:}

Video Pembelajaran

Fisika, Daring, Motivasi

Belajar.

How to Cite: Widianta, I. (2021). Video Pembelajaran Fisika Sebagai Sumber Belajar Daring untuk Meningkatkan Motivasi Belajar Peserta Didik SMAN 9 Mataram di Masa Pandemi Covid-19. Jurnal Paedagogy, 8(3), 377-385. doi:https://doi.org/10.33394/jp.v8i3.3889

\section{Pendahuluan}

Ilmu Pengetahuan Alam menjadi salah satu landasan penting dalam pembangunan bangsa untuk menghadapi tantangan abad 21 yang ditandai dengan perkembangan teknologi yang pesat. Keterampilan belajar dan berinovasi yang meliputi berpikir kritis dan mampu menyelesaikan masalah, kreatif dan inovatif, serta mampu berkomunikasi dan berkolaborasi merupakan salah satu kompetensi yang harus dimiliki peserta didik setelah melaksanakan pembelajaran Ilmu Pengetahuan Alam. Di samping itu, kemampuan yang harus dimiliki peserta didik adalah terampil untuk menggunakan media, teknologi, informasi dan 
komunikasi. Kemampuan peserta didik yang tidak kalah pentingnya adalah kemampuan untuk menjalani kehidupan dan karir, meliputi kemampuan beradaptasi, luwes, berinisiatif, mampu mengembangkan diri, memiliki kemampuan sosial dan budaya, produktif, dapat dipercaya, memiliki jiwa kepemimpinan, dan bertanggung jawab.

Fisika sebagai bagian dari Ilmu Pengetahuan Alam diperoleh dan dikembangkan berdasarkan percobaan untuk mencari jawaban mengenai gejala-gejala alam khususnya yang berkaitan dengan materi dan energi. Dalam proses pembelajaran Fisika dengan pendekatan ilmiah berbasis keilmuan, ranah sikap dimaksudkan agar peserta didik tahu tentang 'mengapa'. Ranah keterampilan dimaksudkan agar peserta didik tahu tentang 'bagaimana'. Sedangkan, ranah pengetahuan dimaksudkan agar peserta didik tahu tentang 'apa'. Dengan mengembangkan ketiga aspek kompetensi tersebut maka diharapkan dapat membentuk siswa yang produktif, kreatif, dan inovatif. Dalam konteks mata pelajaran Fisika SMA, kurikulum Fisika SMA mencakup rencana pengaturan materi pelajaran Fisika, dan cara pembelajaran Fisika untuk mencapai kompetensi. Rencana pengaturan diwujudkan dalam bentuk silabus pembelajaran Fisika, sedangkan rencana pengaturan yang lebih rinci diwujudkan dalam bentuk Rencana Pelaksanaan Pembelajaran (RPP) Fisika. Penyusunan RPP Fisika merupakan tugas dan kewenangan guru, dengan mengacu pada silabus, buku guru, buku siswa, sumber belajar yang tersedia, serta karakteristik siswanya.

Sejak diumumkan pemerintah mengenai kasus pertama Coronavirus Disease 2019 (Covid-19) pada bulan Maret 2020 yang lalu, Indonesia kemudian dihadapkan pada masa pandemi. Hampir seluruh sektor kehidupan terdampak, tidak terkecuali di sektor pendidikan. Covid-19 ini menular begitu cepat dan telah menyebar hampir ke semua negara, termasuk Indonesia, sehingga Badan Kesehatan Dunia (WHO) menjadikan wabah ini sebagai pandemi global pada tanggal 11 Maret 2020 (Asmuni, 2020). Merebaknya kasus penyebaran virus Corona atau Covid-19 sangat berdampak terhadap proses pembelajaran di seluruh wilayah Indonesia tidak terkecuali di Kota Mataram. Pembelajaran jarak jauh (PJJ) menjadi salah satu alternatif yang dipilih oleh pemerintah daerah. Dalam Undang-undang No. 20 tahun 2003 pasal 1 ayat 15, disebutkan bahwa Pendidikan Jarak Jauh adalah pendidikan yang peserta didiknya terpisah dari pendidik dan pembelajarannya menggunakan berbagai sumber belajar melalui teknologi komunikasi, informasi, dan media lain. Dalam pelaksanaannya, PJJ dibagi menjadi dua pendekatan, yaitu pembelajaran jarak jauh dalam jaringan (daring) dan pembelajaran jarak jauh luar jaringan (luring). Belajar dari rumah (BDR) dilaksanakan dengan sistem PJJ ini.

Hasil pengamatan yang telah dilakukan selaku guru fisika terhadap peserta didik di kelas X MIA 3 SMAN 9 Mataram menunjukkan bahwa selama pertengahan semester genap tahun pelajaran 2019/2020 yang berlangsung di masa pandemi covid-19, motivasi belajar peserta didik dalam pembelajaran fisika mengalami penurunan. Pembelajaran jarak jauh secara daring dengan metode penugasan melalui kelas maya Google Classroom dan sumber belajar berupa buku paket seperti BSE atau e-modul, tidak mampu membangkitkan motivasi belajar fisika peserta didik.

Karena itu persiapan dan pelaksanaan pembelajarannya diatur ulang dengan harapan agar motivasi belajar peserta didik dapat bangkit kembali. Sarana pembelajaran seperti smartphone atau laptop serta kuota internet disediakan oleh orang tua peserta didik. Media pembelajaran dan sumber berlajar dipilih oleh guru dengan mempertimbangkan efektifitas dan efisiensinya. Khusus untuk pembelajaran fisika, media pembelajaran yang dipilih adalah kelas maya Google Classroom dan channel berbagi video Youtube.com. Pemanfaatan kelas maya Google Classroom sebagai media pembelajaran dipilih dengan mempertimbangkan 
kemudahan akses dan kelengkapan fitur kelas mayanya. Melalui kelas maya Google Classroom ini, peserta didik dapat memperoleh materi pelajaran dan tugas-tugas belajar serta soal-soal penilaian melalui fitur Classwork (Tugas Kelas) dan mendapat bimbingan serta melakukan diskusi (tanya jawab) melalui fitur Stream (forum). Sedangkan pemanfaatan channel Youtube.com sebagai media pembelajaran dipilih dengan mempertimbangkan kemudahan akses dan adanya fitur berbagi videonya. Guru membagikan Video Pembelajaran Fisika kepada peserta didik melalui akun Narta Widianta pada channel Youtube.com. Sumber belajar yang digunakan dalam kegiatan pembelajaran berupa Video Pembelajaran Fisika dirancang dan dibuat oleh peneliti selaku guru fisika dengan mempertimbangkan fungsi media sebagai pembangkit motivasi belajar peserta didik.

Agnew dan Kellerman dalam Munir (2015) mendefinisikan video sebagai media digital yang menunjukkan susunan atau urutan gambar-gambar bergerak dan dapat memberikan ilusi/fantasi. Video juga sebagai sarana untuk menyampaikan informasi yang menarik, langsung dan efektif. Video pada multimedia digunakan untuk menggambarkan suatu kegiatan atau aksi. Menurut Hamalik dalam Arsyad (2014) bahwa pemakaian media pembelajaran dalam proses belajar mengajar dapat membangkitkan keinginan dan minat yang baru, membangkitkan motivasi dan rangsangan kegiatan belajar dan bahkan membawa pengaruh-pengaruh psikologis terhadap siswa. Livie \& Lentz dalam Arsyad (2014) mengemukakan bahwa fungsi atensi media visual merupakan inti yaitu menarik dan mengarahkan perhatian siswa untuk berkonsentrasi kepada isi pelajaran yang berkaitan dengan makna visual yang ditampilkan atau menyertai teks materi pelajaran.

Terkait dengan motivasi belajar, Sardiman (2012) mengemukakan bahwa intensitas motivasi seorang siswa akan sangat menentukan tingkat pencapaian prestasi belajarnya. Sedangkan Keller dalam Wena (2019) mendefinisikan motivasi sebagai intensitas dan arah suatu perilaku serta berkaitan dengan pilihan yang dibuat seseorang untuk mengerjakan atau menghindari suatu tugas serta menunjukkan tingkat usaha yang dilakukannya. Selanjutnya Keller mengemukakan bahwa mengingat usaha merupakan indikator langsung dari motivasi belajar maka secara operasional motivasi belajar ditentukan oleh tingkat perhatian siswa terhadap pembelajaran, tingkat relevansi pembelajaran dengan kebutuhan siswa, tingkat keyakinan siswa terhadap kemampuannya dalam mengerjakan tugas-tugas pembelajaran dan tingkat kepuasan siswa terhadap proses pembelajaran yang telah dilaksanakan.

Motivasi belajar peserta didik ternyata terkait erat dengan pemanfaatan video pembelajaran seperti terungkap pada beberapa hasil penelitian. Ketut Agustini dan Jero Gede Ngarti (2020), mengemukan bahwa video pembelajaran membawa dampak positif bagi kegiatan belajar peserta didik seperti demontrasi materi, motivasi, tutorial, dan efektivitas waktu. Setyorini (2016), menemukan bahwa penggunaan Media Video dan Metode Curah Pendapat berpengaruh secara signifikan terhadap Motivasi Belajar Siswa SMP Negeri I Kec. Babadan Kabupaten Ponorogo pada Mata Pelajaran IPS Kelas IX Tahun Pelajaran 2015/2016. Sedangkan Putri Maisyarah Ammy dan Sri Wahyuni (2020), menyatakan bahwa dengan menggunakan video pembelajaran materi yang disampaikan menunjukkan $90 \%$ mahasiswa memiliki motivasi belajar yang tinggi dalam belajar dan dengan menggunakan video pembelajaran juga menjadi alternatif untuk mahasiswa dapat belajar dan memahami dengan baik.

Video Pembelajaran Fisika yang digunakan dalam penelitian ini terbentuk dari kombinasi multimedia berupa teks, gambar, movie clip, narasi penjelasan guru fisika, dan musik latar. Video ini terdiri dari dua jenis yaitu video penjelasan materi pelajaran fisika dan video demonstrasi eksperimen fisika. Penjelasan materi pelajaran fisika pada video itu 
diawali dengan penayangan movie clip tentang berbagai gejala alam terkait materi pokok yang sedang dipelajari peserta didik. Selanjutnya ditayangkan berbagai masalah yang terkait dengan gejala alam dan materi pelajaran, kemudian disajikan juga peta konsep yang merupakan gambaran konsep-konsep dan hubungan antar konsep yang sedang dipelajari, lalu disajikan pula penjelasan tentang analisis materi pelajaran dan penjelasan cara memecahkan masalah pada contoh soal. Sedangkan video eksperimen fisika berisi penjelasan tentang eksperimen terkait dengan materi pokok yang sedang dipelajari. Pada video ini dijelaskan tentang tujuan eksperimen, alat dan bahan eksperimen, prosedur melakukan eksperimen, prosedur pengamatan dan pengambilan data hasil pengamatan serta prosedur analisis data.

Dengan cara menonton Video Pembelajaran Fisika, peserta didik akan dilatih untuk melakukan literasi sekaligus mendapatkan penjelasan materi pelajaran dari guru secara lisan melalui narasi penjelasan guru di video tersebut. Selanjutnya peserta didik dapat merangkum sendiri materi-materi penting dengan berpatokan pada beberapa masalah yang diajukan pada video itu atau menambahkan sendiri sesuai kemampuan peserta didik. Dengan menyimak peta konsep pada video itu, peserta didik dapat mengetahui jenis dan jumlah konsep-konsep dan hubungan antar konsep-konsep yang sedang dipelajari. Jika ada hal-hal yang belum dipahami oleh peserta didik, maka guru menjadwalkan kegiatan pembimbingan melalui pembelajaran daring (online) dengan media kelas maya Google Classroom. Melalui kelas maya ini, peserta didik juga dapat melakukan diskusi dan tanya jawab dengan guru atau teman-temannya, mengakses tugas-tugas belajar, mengakses soal-soal penilaian dan mengakses nilai hasil belajarnya.

Komponen-komponen dalam Video Pembelajaran Fisika yang diterapkan dengan pendekatan seperti ini diharapkan dapat menarik perhatian peserta didik selama kegiatan pembelajaran, sesuai dengan kebutuhan peserta didik, menyebabkan peserta didik merasa yakin dengan kemampuannya dan menyebabkan peserta didik merasa puas terhadap proses pembelajaran yang telah dilaksanakan. Adapun tujuan penelitian ini adalah untuk meningkatkan motivasi belajar peserta didik kelas X MIA 3 SMAN 9 Mataram tahun pelajaran 2020/2021 melalui video pembelajaran fisika dalam pembelajaran jarak jauh secara daring di masa pandemi Covid-19.

\section{Metode Penelitian}

Penelitian ini merupakan penelitian kualitatif, yaitu metode penelitian yang digunakan untuk meneliti pada kondisi objek yang alamiah, dimana peneliti sebagai instrumen kunci (Sugiyono dalam Putri dan Sri: 2020). Penelitian ini dilakukan untuk mengetahui seberapa besar motivasi belajar peserta didik kelas X MIA 3 SMAN 9 Mataram pada semester ganjil tahun pelajaran 2020/2021 setelah menggunakan Video Pembelajaran Fisika sebagai sumber belajar dalam pembelajaran jarak jauh secara daring melalui Google Classroom dan Youtube.com. Video Pembelajaran Fisika tersebut dibuat oleh peneliti dan berisi materi pelajaran fisika sesuai Kurikulum 2013 revisi. Materi pokok yang dibahas dalam Video Pembelajaran Fisika itu meliputi Hakikat Fisika, Pengukuran, Vektor, Gerak Lurus, Gerak Parabola dan Gerak Melingkar.

Penelitian ini dilakukan selama satu semester, dimulai dari tanggal 29 Juli 2020 sampai dengan 4 Desember 2020. Subyek penelitian ini adalah peserta didik kelas X MIA 3 SMAN 9 Mataram Tahun Pelajaran 2020/2021 yang berjumlah 35 orang yang terdiri dari 15 orang laki-laki dan 20 orang perempuan. Instrumen penelitian ini terdiri dari angket motivasi belajar peserta didik yang disusun berdasarkan pendapat Keller dalam Wena (2019) bahwa secara operasional motivasi belajar ditentukan oleh tingkat perhatian siswa terhadap 
pembelajaran, tingkat relevansi pembelajaran dengan kebutuhan siswa, tingkat keyakinan siswa terhadap kemampuannya dalam mengerjakan tugas-tugas pembelajaran dan tingkat kepuasan siswa terhadap proses pembelajaran yang telah dilaksanakan. Berdasarkan empat indikator motivasi belajar seperti yang dikemukakan Keller tersebut, kemudian disusun 17 pernyataan dengan 4 pilihan pendapat yaitu sangat setuju, setuju, tidak setuju dan sangat tidak setuju. Skor pada masing-masing pernyataan tersebut sebesar 4 untuk pendapat sangat setuju, 3 untuk pendapat setuju, 2 untuk pendapat tidak setuju dan 1 untuk pendapat sangat tidak setuju sehingga skor maksimal yang diperoleh peserta didik adalah 68 dan skor minimalnya sebesar 17. Selanjutnya, angket tersebut diberikan kepada peserta didik setelah melakukan kegiatan pembelajaran selama satu semester. Setelah peserta didik memberikan pendapatnya, maka data yang diperoleh dari angket tersebut dianalisis secara deskriptif dengan cara disusun dalam bentuk tabel kemudian dilakukan perhitungan untuk mengetahui nilai persentase jumlah peserta didik yang memiliki motivasi pada kategori sangat tinggi, tinggi, sedang, rendah dan sangat rendah.

Untuk mengetahui persentase keaktifan peserta didik dalam mengikuti kegiatan pembelajaran maka peneliti melakukan observasi selama berlangsungnya kegiatan pembelajaran. Data yang diperoleh dari hasil observasi itu adalah persentase kehadiran peserta didik saat mengikuti kegiatan pertemuan secara daring di Google Classroom dan data persentase keaktifan peserta didik dalam menyelesaikan tugas-tugas belajarnya. Tugas-tugas belajar peserta didik per kompetensi dasar terdiri dari tugas pertama yaitu mengerjakan rangkuman dan latihan soal yang dilakukan sebelum dan sesudah mengikuti pertemuan daring di Google Classroom, tugas kedua adalah mengerjakan soal ulangan harian yang dilakukan sesuai jadwal secara daring di Google Classroom dan tugas ketiga adalah mengerjakan tugas proyek selama batas waktu tertentu dan dikirim secara daring melalui Google Classroom. Sedangkan wawancara juga dilakukan oleh peneliti selama dan setelah berlangsungnya kegiatan pembelajaran untuk mengetahui kendala-kendala yang dihadapi peserta didik dalam mengikuti kegiatan pembelajaran secara daring tersebut.

\section{Hasil Penelitian dan Pembahasan}

Berdasarkan hasil observasi terhadap kegiatan pembelajaran jarak jauh secara daring melalui Google Classroom dengan penerapan Video Pembelajaran Fisika sebagai sumber belajar bagi peserta didik kelas X MIA 3 SMAN 9 Mataram selama semester ganjil tahun pelajaran 2020/2021, maka diperoleh bahwa kegiatan pembelajaran berlangsung cukup kondusif yang ditunjukkan oleh indikator berupa rata-rata persentase kehadiran peserta didik pada pertemuan di kelas maya Google Classroom mencapai $73 \%$ dengan jumlah persentase peserta didik yang aktif melakukan tanya jawab mencapai lebih dari 50\% dan rata-rata tugas belajar yang bisa diselesaikan oleh seluruh peserta didik selama satu semester mencapai 85\%. Hal ini menunjukkan bahwa peserta didik cukup antusias mengikuti kegiatan pembelajaran jarak jauh secara daring. Sedangkan melalui wawancara terhadap peserta didik terungkap bahwa beberapa peserta didik masih terkendala oleh keberadaan sarana pembelajaran daring berupa smartphone atau laptop yang kurang memadai dan keterbatasan kuota internet yang dimiliki peserta didik. Kendala inilah yang mungkin menjadi penyebab utama rendahnya partisipasi aktif beberapa peserta didik dalam pembelajaran daring sehingga berpengaruh pada persentase keaktifan kegiatan pembelajaran secara keseluruhan.

Berdasarkan hasil analisis data angket motivasi belajar peserta didik yang diisi oleh peserta didik setelah melakukan kegiatan pembelajaran jarak jauh secara daring dengan penerapan Video Pembelajaran Fisika sebagai sumber belajar peserta didik, maka diperoleh 
grafik skor motivasi belajar peserta didik seperti ditunjukkan pada gambar 1 dan diperoleh pula data persentase jumlah peserta didik pada setiap kategori motivasi belajar seperti diperlihatkan pada tabel 1. Pada gambar 1, dapat dilihat bahwa skor motivasi belajar peserta didik berkisar antara 40 sampai 63 dengan nilai rata-rata sebesar 54. Sedangkan pada tabel 1 dapat diamati bahwa $40 \%$ peserta didik memiliki motivasi belajar dalam kategori sangat tinggi, 49\% memiliki motivasi belajar dalam kategori tinggi, 11\% memiliki motivasi belajar sedang dan tidak ada peserta didik yang memiliki motivasi belajar dalam kategori rendah dan sangat rendah.

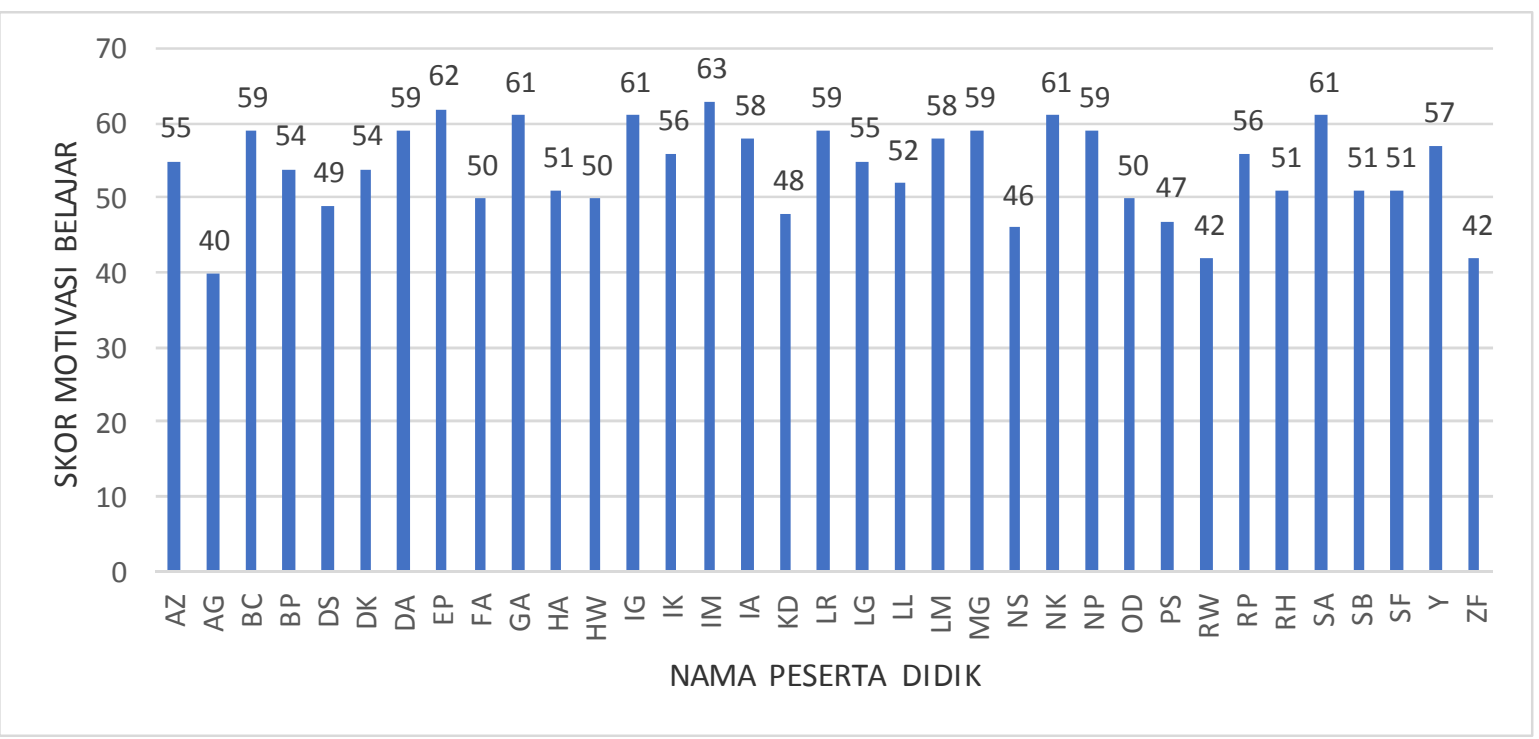

Gambar 1. Grafik Skor Motivasi Belajar Peserta Didik

Tabel 1. Persentase Jumlah Peserta Didik Kelas 10 MIA 3 SMAN 9 Mataram pada

Setiap Kategori Motivasi Belajar Setelah Mengikuti Kegiatan Pembelajaran Jarak Jauh Secara Daring dengan Penerapan Video Pembelajaran Fisika.

\begin{tabular}{cccc}
\hline No. & Kategori & Skor & Persentase \\
\hline 1 & Sangat Tinggi & $57-68$ & $40 \%$ \\
2 & Tinggi & $47-56$ & $49 \%$ \\
3 & Sedang & $37-46$ & $11 \%$ \\
4 & Rendah & $27-36$ & $0 \%$ \\
5 & Sangat Rendah & $17-26$ & $0 \%$ \\
\hline
\end{tabular}

Nilai rata-rata sebesar 54 pada skor motivasi belajar peserta didik tersebut menunjukkan bahwa rata-rata peserta didik kelas X MIA 3 memiliki motivasi belajar fisika pada kategori tinggi setelah mereka mengikuti kegiatan pembelajaran jarak jauh secara daring dengan menggunakan Video Pembelajaran Fisika sebagai sumber belajarnya. Sebagian peserta didik yaitu $40 \%$ sangat termotivasi untuk belajar fisika, $49 \%$ termotivasi untuk belajar fisika dan sebagian kecil peserta didik yaitu $11 \%$ cukup termotivasi dalam belajar fisika setelah melakukan kegiatan pembelajaran dengan pendekatan ini. Tingginya motivasi belajar peserta didik itu mengindikasikan telah berfungsinya Video Pembelajaran Fisika sebagai sumber belajar yang dapat membangkitkan motivasi belajar peserta didik. Hal ini sesuai dengan pendapat para ahli. Agnew dan Kellerman dalam Munir (2015) mendefinisikan video sebagai media digital yang menunjukkan susunan atau urutan gambar-gambar bergerak dan dapat memberikan ilusi/fantasi. Video juga sebagai sarana untuk menyampaikan informasi yang menarik, langsung dan efektif. Video pada multimedia digunakan untuk 
menggambarkan suatu kegiatan atau aksi. Menurut Hamalik dalam Arsyad (2014) bahwa pemakaian media pembelajaran dalam proses belajar mengajar dapat membangkitkan keinginan dan minat yang baru, membangkitkan motivasi dan rangsangan kegiatan belajar dan bahkan membawa pengaruh-pengaruh psikologis terhadap siswa. Livie \& Lentz dalam Arsyad (2014) mengemukakan bahwa fungsi atensi media visual merupakan inti yaitu menarik dan mengarahkan perhatian siswa untuk berkonsentrasi kepada isi pelajaran yang berkaitan dengan makna visual yang ditampilkan atau menyertai teks materi pelajaran. Keberadaan Video Pembelajaran Fisika dalam kegiatan pembelajaran fisika berhasil menarik perhatian peserta didik selama kegiatan pembelajaran, sesuai dengan kebutuhan peserta didik, menyebabkan peserta didik merasa yakin dengan kemampuannya dan menyebabkan peserta didik merasa puas terhadap proses pembelajaran yang telah dilaksanakan.

Hasil penelitian ini juga sesuai dengan hasil beberapa penelitian yang mengaitkan antara pemanfaatan video pembelajaran dengan motivasi belajar peserta didik. Penelitian yang dilakukan oleh Ketut Agustini dan Jero Gede Ngarti (2020) menemukan bahwa video pembelajaran membawa dampak positif bagi kegiatan belajar peserta didik seperti demontrasi materi, motivasi, tutorial, dan efektivitas waktu. Penelitian yang dilakukan oleh Setyorini (2016) menyatakan bahwa penggunaan Media Video dan Metode Curah Pendapat berpengaruh secara signifikan terhadap Motivasi Belajar Siswa SMP Negeri I Kec. Babadan Kabupaten Ponorogo pada Mata Pelajaran IPS Kelas IX Tahun Pelajaran 2015/2016. Dan penelitian yang dilakukan oleh Putri Maisyarah Ammy dan Sri Wahyuni (2020) mendapatkan hasil bahwa dengan menggunakan video pembelajaran materi yang disampaikan menunjukkan 90\% mahasiswa memiliki motivasi belajar yang tinggi dalam belajar dan dengan menggunakan video pembelajaran juga menjadi alternatif untuk mahasiswa dapat belajar dan memahami dengan baik.

Beberapa hal terkait dengan komponen Video Pembelajaran Fisika yang menyebabkan peserta didik merasa termotivasi untuk belajar fisika antara lain kemudahan mengakses video melalui channel youtube.com, desain video yang menarik, isi materi video berupa: gejala alam, masalah, peta konsep, analisis materi pelajaran, numerasi pada contoh soal dan narasi guru fisika dalam video yang menyebabkan materi pelajaran lebih mudah dipahami. Sebagian besar peserta didik juga merasa setuju bahwa setelah melakukan kegiatan pembelajaran dengan penerapan Video Pembelajaran Fisika ini, mereka tertarik untuk mengerjakan tugas-tugas, tertarik untuk bertanya tentang hal-hal yang belum dipahami, tertarik untuk menonton video secara berulang-ulang, menjadi paham tentang tujuan dan manfaat belajar fisika, bisa mengaitkan materi yang dipelajari dengan kehidupan sehari-hari, merasa cocok menggunakan video pembelajaran dalam belajar fisika, merasa yakin dengan kemampuan dan hasil pekerjaannya, merasa puas karena bisa memahami materi dan menerapkannya dalam menyelesaikan tugas-tugas belajar.

Dengan demikian, maka penerapan Video Pembelajaran Fisika sebagai sumber belajar dalam pembelajaran jarak jauh secara daring pada peserta didik kelas X MIA 3 SMAN 9 Mataram selama masa pandemi Covid-19 di semester ganjil tahun pelajaran 2020/2021 dapat dikatakan telah berhasil dalam membangkitkan motivasi belajar fisika sehingga rata-rata peserta didik memiliki motivasi belajar pada kategori tinggi

\section{Kesimpulan}

Berdasarkan hasil penelitian dan pembahasan yang telah dipaparkan, maka dapat disimpulkan bahwa penerapan video pembelajaran fisika sebagai sumber belajar dalam pembelajaran jarak jauh secara daring pada peserta didik kelas X MIA 3 SMAN 9 Mataram 
selama masa pandemi Covid-19 di semester ganjil tahun pelajaran 2020/2021 dapat meningkatkan motivasi belajar fisika sehingga rata-rata peserta didik memiliki motivasi belajar pada kategori tinggi.

\section{Saran}

Berdasarkan temuan yang diperoleh dari penelitan ini maka saran yang bisa disampaikan antara lain: 1) untuk guru fisika yang ingin menerapkan pendekatan pembelajaran ini, perlu memastikan kelengkapan sarana pembelajaran terutama smartphone atau laptop dengan spesifikasi yang memadai serta ketersediaan kuota internet dan memotivasi seluruh peserta didik agar mengikuti semua tahapan pembelajaran; 2) sekolah perlu mendukung ketersediaan komputer dan kuota internet bagi peserta didik yang tidak mampu menyediakan sarana belajar secara mandiri; dan (3) untuk pengembangan penelitian lebih lanjut perlu diadakan penelitian serupa di sekolah lain pada mata pelajaran lain.

\section{Daftar Pustaka}

A.Wahab Jufri. (2013). Belajar dan Pembelajaran.Bandung: Pustaka Reka Cipta

Afrita Heksa. (2020). Pembelajaran Inkuiri di Masa Pandemi.Yogyakarta: Deepublish

Agustini, Ketut dan Jero Gede Ngarti. (2020). Pengembangan Video Pembelajaran Untuk Meningkatkan Motivasi Belajar Siswa Menggunakan Model R\&D. Jurnal Imiah $\begin{array}{lllll}\text { Pendidikan dan } & \text { Pembelajaran (JIPP), }\end{array}$ DOI: http://dx.doi.org/10.23887/jipp.v4i1.18403

Ahmad Susanto. (2016). Teori Belajar dan Pembelajaran di Sekolah Dasar.Prenadamedia Group: Jakarta

Asmuni, A. (2020). Problematika Pembelajaran Daring di Masa Pandemi Covid-19 dan Solusi Pemecahannya. Jurnal Paedagogy, 7(4), 281-288. doi:https://doi.org/10.33394/jp.v7i4.2941

Aqib, Zainal. (2017). Model-model, Media dan Strategi Pembelajaran Kontekstual (Inovatif). Bandung: Yrama Widya

Azhar Arsyad. (2014). Media Pembelajaran.Jakarta: PT.RajaGrafindo Persada

Cahyadi, Ani. (2019). Pengembangan Media dan Sumber Belajar, Teori dan Prosedur. Serang: Laksita Indonesia

Dina Gasong. (2018). Belajar dan Pembelajaran. Yogyakarta: Deepublish

Firmina Angela Nai. (2017). Teori Belajar dan Pembelajaran Implementasinya dalam Pembelajaran di SMP,SMA dan SMK.Yogyakarta: Deepublish

Hamalik, Oemar. (2014). Psikologi Belajar dan Mengajar.Bandung: Sinar Baru Algensindo

Husamah dkk. (2018). Belajar dan Pembelajaran. Malang: Universitas Muhammadiyah Malang

Kementerian Pendidikan dan Kebudayaan.(2017). Model Silabus Mata Pelajaran Sekolah Menengah Atas/ Madrasah Aliyah (SMA/MA) Mata Pelajaran Fisika. Jakarta: Kementerian Pendidikan dan Kebudayaan.

Kompri. (2018). Motivasi Pembelajaran Perspektif Guru dan Siswa.Bandung: PT. Remaja Rosdakarya.

Lefudin. (2017). Belajar dan Pembelajaran. Yogyakarta: Deepublish

Muhammad Fathurrohman. (2015). Model-model Pembelajaran Inovatif. Jogjakarta: Ar-ruzz Media.

Muhammad Fathurrohman. (2017). Belajar dan Pembelajaran_Modern. Yogyakarta: Garudhawaca 
Munir. (2015). Multimedia Konsep \& Aplikasi dalam Pendidikan.Bandung: Alfabeta

Ngalimun dkk. (2014). Strategi dan Model Pembelajaran. Banjar Baru Kalimantan Selatan: Scripta Cendikia

Putri Maisyarah Ammy dan Sri Wahyuni.(2020). Analisis Motivasi Belajar Mahasiswa Menggunakan Video Pembelajaran Sebagai Alternatif Pembelajaran Jarak Jauh (PJJ). Jurnal Matematics Paedagogic, V(1).DOI: https://doi.org/10.36294/jmp.vxix.xxx

Ridwan Abdullah Sani, Rahmatsyah dan Wawan Bunawan.(2019).Soal Fisika Hots.Jakarta: Bumi Aksara.

Rusman. (2017). Belajar dan Pembelajaran Berorientasi Standar Proses Pendidikan. Jakarta: Kencana

Sardiman, AM. (2012).Interaksi dan Motivasi Belajar Mengajar.Jakarta: PT.RajaGrafindo Persada

Setyorini, S. (2016). Pengaruh Penggunaan Media Pembelajaran Video dan Metode Curah Pendapat Terhadap Motivasi Belajar Siswa Pendidikan Ilmu Pengetahuan Sosial. Jurnal Penelitian Dan Pendidikan IPS, 10(3), 356-362. https://ejournal.unikama.ac.id/index.php/JPPI/article/view/1686.

Nurkhasanah, S. (2021). Implementasi Model Pembelajaran Flipped Classroom dalam Pembelajaran Jarak Jauh untuk Meningkatkan Partisipasi Belajar IPA. Jurnal Paedagogy, 8(2), 256-263. doi:https://doi.org/10.33394/jp.v8i2.3532

Slameto. (2013). Belajar dan Faktor-faktor yang Mempengaruhi.Jakarta: Rineka Cipta.

Soekarman, S. (2021). Impementasi Pembelajaran Fisika Pokok Bahasan Elastisitas Melalui Inquiry Based Learning di SMA Negeri 2 Donggo. Jurnal Paedagogy, 8(2), 197209. DOI:https://doi.org/10.33394/jp.v8i2.3521

Trianto. (2012). Mendesain Model Pembelajaran Inovatif-Progresif. Jakarta: Kencana Uno, Hamzah B. (2012). Teori Motivasi dan Pengukurannya Analisis di Bidang Pendidikan. Jakarta: PT.Bumi Aksara.

Warsona dan Hariyanto. (2012). Pembelajaran Aktif. Bandung: Remaja Rosdakarya Wena, Made. (2019). Strategi Pembelajaran Inovatif Kontemporer.Jakarta: Bumi Aksara Yatim Riyanto. (2014). Paradigma Baru Pembelajaran. Jakarta: Prenadamedia Group 